\title{
PENGARUH PERILAKU MASYARAKAT MEMBUANG SAMPAH DI SUNGAI
}

Jihan ayu alip pristananda

STIKes Surya Mitra Husada

\section{jiehanayu@gmail.com}

\begin{abstract}
Abstrak
Salah satu permasalahan yang ada di Indonesia adalah kebersihan lingkungan. Kasus-kasus yang menyangkut masalah kebersihan setiap tahunnya selalu meningkat. Dan sampah adalah salah satu faktor penyebab kurangnya masalah kebersihan. Perilaku masyarakat dalam membuang sampah ke sungai, dikarenakan sungai dinilai sebagai tempat yang gratis, praktis, serta telah menjadi kebiasaan dari masyarakat tanpa memperdulikan dampak negatifnya.
\end{abstract}

kata kunci : Perilaku, sampah, dampak

\section{Latar Belakang}

Di Indonesia, masalah kebersihan selalu menjadi polemik yang berkembang.. Kebersihan lingkungan merupakan salah satu tolak ukur kualitas hidup masyarakat. Masyarakat masih menganggap sungai sebagai halaman belakang yang dipandang sebagai tempat pembuangan, sehingga perlu adanya perubahan pola pikir untuk menjadikan sungai sebagai halaman depan yang harus dijaga dan dipelihara. Mengingat masyarakat merupakan pengguna sungai, 
maka persepsi masyarakat mengenai pengetahuan menjaga kualitas lingkungan sungai dan kesanggupan dalam melakukan aktivitas dengan tetap menjaga kelestarian sungai menjadi penting untuk dikaji.

Perilaku manusia yang tidak bertanggung jawab terhadap sampah dapat menyebabkan munculnya masalah dan kerusakan lingkungan. Bila perilaku manusia semata-mata mengarah lebih pada kepentingan pribadinya, dan kurang atau tidak mempertimbangkan

kepentingan umum / kepentingan bersama, maka dapat diprediksi bahwa daya dukung lingkungan alam semakin terkuras habis dan akibatnya kerugian dan kerusakan lingkungan tak dapat dihindarkan lagi.

\section{Kasus/Masalah}

Salah satu sumber utama pencemaran sungai di Negara berkembang berasal dari pembuangan sampah di badan air. Sampah mengganggu estetika kawasan tepian sungai. Selain itu, sampah juga menjadi tempat berkembangnya vektor penyakit, mengurangi kenyamanan dan menimbulkan banjir. Sampah sebagai pencemar di sungai dapat mengakibatkan terbentuknya sedimen sehingga sungai menjadi dangkal, kadar total suspended solid meningkat dan dissolve oksigen menurun. Kondisi ini secara otomatis mempengaruhi rantai makanan dan ekosistem yang ada di sungai.

\section{Tinjauan pustaka}

Menurut Entjang (1987), Sampah adalah zat-zat atau benda-benda yang tidak dipakai 
lagi, baik berasal dari rumah tangga maupun sisa-sisa industri. Dalam pengertian lain sampah adalah segala sesuatu yang tidak dikehendaki oleh yang punya dan bersifat padat, ada yang mudah membusuk terutama sampah yang terdiri dari zat-zat organik seperti sisa sayuran, sisa daging, daun dan sebagainya. Sedangkan yang tidak dapat membusuk dapat berupa kertas, karet, logam, kaca, plastik, dan sebagainya (slamet, 1994)

Sehubung dengan hal diatas, maka Leonardo (1990) mengatakan bahwa limbah padat merupakan salah satu bentuk limbah yang terdapat di lingkungan masyarakat, orang awam menyebutnya dengan sampah. Sampah dan kesehatan lingkungan sebenarnya hanya sebagian dari benda atau hal-hal yang dipandang tidak dapat digunakan lagi, tidak dipakai tidak disenangi, atau harus dibuang sedemikian rupa sehingga tidak sampai mengganggu kelangsungan hidup.

Menurut Azwar, perilaku adalah suatu kecenderungan untuk memberikan respon terhadap suatu objek atau sekumpulan objek dalam bentuk perasaan memihak (favourable) maupun tidak memihak (unfavourable) melalui proses interaksi komponen-komponen sikap yaitu kognitif (pengetahuan), afektif (perasaan) dan konatif (kecendrungan bertindak). perilaku subjek yang baik terhadap perilaku membuang sampah merupakan perasaan yang memihak atau mendukung terhadap upaya berperilaku baik dalam membuang sampah. 


\section{Pembahasan}

Menurut World Health Organization (WHO) pada pusat kesehatan yang mengaumi masyarakat Amerika membuat batasan tentang sampah, dalam hal ini sampah merupakan sesuatu hal yang sudah tidak berguna, tidak dapat dipakai lagi dan sesuatu yang biasanya terbuang dan tidak dapat bermanfaat bagi kehidupan manusia ataupun pada kehidupan mahluk lain lagi.

\section{Dampak sampah bagi} manusia dan lingkungan

Pencemaran lingkungan akibat sampah industri dan sampah rumah tangga yang dihasilkan sangatlah merugikan manusia, baik langsung dan tidak tidak langsung. Dampak sampah tersebut berupa :

1. Dampak bagi kesehatan

Lokasi dan pengelolaan sampah yang kurang memadai merupakan tempat yang cocok bagi beberapa ornganisme dan menarik bagi berbagai binatang seperti lalat dan anjing yang dapat menimbulkan penyakit. Potensi behaya kesehatan yang dapat di timbulkan adalah sebagai berikut :

a. Penyakut diare, kolera, tifus, menyebar dengan cepat karena virus yang berasal dari sampah dengan pengelolaan tidak tepat dapat bercampur air minum.

b. Penyakit jamur dapat menyebar misalnya jamur kulit.

c. Penyakit yang dapat menyebar melalui rantai makanan. Salah satu contohnya adalah suatu penyakitr yang dijangkitkan oleh cacing pita. Cacing ini sebenarnya masuk ke dalam pencernaan binatang ternak 
melalui makananya berupa sisa makanan/sampah.

d. Sampah beracun seperti sampah buangan limbah pabrik yan memproduksi bakteri dan akumulator.

2. Dampak terhadap lingkungan

Cairan rembesan sampah yang masuk ke dalam drainase/sungai dapat mencemari air. Berbagai organisme termasuk ikan dapat mati sehingga beberapa spesies akan lenyap hal ini mengakibatkan berubahnya ekosistem perairan biologis. Penguraian sampah yang dibuang ke dalam air akan menghasilkan asam organik dan gas cair organik, seperti metaba. Selain berbau kurang sedap, gas ini dalam konsentrasi tinggi dapat meledak.
3. Dampak terhadap keadaan sosial dan ekonomi.

a. Pengelolaan sampah yang kurang baik akan membentuk lingkungan yang kurang menyenangkan bagi masyarakat, seperti bau yang tidak sedap dan pemandangan yang buruk karena sampah yang bertebaran dimana-mana.

b. Memberikan dampak negatif terhadap kepariwisataan.

c. Pengelolaan sampah yang tidak memadai menyebabkan rendahnya tingkat kesehatan masyarakat. Hal penting disini meningkatnya pembiayaan secara langsung (untuk mengobati orang sakit) dan pembiayaan secara tidak langsung (tidak 
masuk kerja, rendahnya produktifitas)

d. Pembuangan sampah padat ke badan air dapat menyebabkan banjir dan akan memberikan dampak bagi fasilitas pelayanan umum seperti jalan, jembatan, drainase dan lain-lain.

Penyebab utama bagaimana perilaku membuang sampah sembarangan ini bisa terbentuk dan bertahan kuat di dalam perilaku adalah:

1. Sistem kepercayaan masyarakat terhadap perilaku membuang sampah. Sangatlah mungkin masyarakat merasa bahwa perilaku membuang sampah sembarangan ini bukan suatu hal yang salah dan tidak berdosa.
2. Norma dari lingkungan sekitar seperti keluarga, tetangga, sekolah, lingkungan kampus, atau bahkan di tempat-tempat pekerjaan. Pengaruh lingkungan merupakan suatu faktor besar di dalam munculnya suatu perilaku. Perilaku membuang sampah sembarangan ini tentu tidak akan pernah lepas dari pengaruh lingkungan sekitar.

3. Kontrol perilaku yang dirasakan seseorang akan melakukan suatu tindakan yang dirasa lebih mudah untuk dilakukannya karena tersedianya sumber daya. Jadi, orang tidak akan membuang sampah sembarangan bila 
tersedia banyak tempat sampah di pinggir jalan.

\section{Kesimpulan}

Berdasarkan pemaparan di atas dapat disimpulkan bahwa sampah ialah material yang sudah tidak diinginkan lagi. Menurut para ahli, masalah sampah juga terkait dengan masalah budaya dan sosiologi masyarakat Indonesia.

Sampah dapat menimbulkan berbagai masalah, baik bagi tanah, udara dan air. Dampak negatif sampah bagi lingkungan adalah sampah mempunyai cairan yang dapat merembes kedalam tanah dan akan mencemari air tanah. Berbagai macam spesies yang hidup di air pun akan terkena dampaknya yaitu kematian bahkan kepunahan spesies tersebut. Sampah yang dibuang kedalam air akan menghasilkan gas hasil penguraiannya yaitu asam organik dan gas-gas cair organik, seperti metana. Gas ini mempunyai bau yang kurang sedap bahkan bisa meledak dalam konsentrasi yang tinggi.

\section{Daftar Pustaka}

Puspitasari, D. E. (2009). Dampak pencemaran air terhadap kesehatan lingkungan dalam perspektif hukum lingkungan (Studi kasus sungai Code di Kelurahan Wirogunan

Kecamatan Mergangsan dan Kelurahan Prawirodirjan

Kecamatan Gondomanan Yogyakarta). Mimbar Hukum-Fakultas Hukum Unversitas Gadjah Mada, 21(1), 23-34.

Setyowati, R., \& Mulasari, S. A. (2013). Pengetahuan dan perilaku ibu rumah tangga dalam pengelolaan sampah 
plastik. Kesmas: National Public Health

Journal, 7(12), 562-566

Wibowo, I. (2009). Pola perilaku kebersihan: Studi psikologi lingkungan tentang penanggulangan sampah perkotaan. Makara, Sosial Humaniora, 13(1), 37-47.

Riswan, R., Sunoko, H. R., \& Hadiyarto, A. (2011). Pengelolaan sampah rumah tangga di Kecamatan Daha Selatan. Jurnal Ilmu Lingkungan, 9(1), 31-38.

Sari, D. (2016). Peran Dinas Kebersihan Dalam Pengelolaan Sampah Rumah Tangga di TPA Terjun Kecamatan Medan Marelan.

Hermawan, Y. (2015). Hubungan antara Tingkat Pendidikan dan Persepsi dengan Perilaku Ibu Rumah Tangga dalam Pemeliharaan Kebersihan Lingkungan.

Bumi Lestari, 5(2).

Fatih, Fadhil. 2013. Makalah Perilaku Buang Sampah Sembarangan. https://fatihfadhil.wordpre ss.com/2013/11/04/makala h-perilaku-buang-sampahsembarangan 